\title{
THE IMPACT OF HISTORICAL POST-EXCAVATION MODIFICATIONS ON THE RE-EXAMINATION OF HUMAN MUMMIES
}

\author{
Heather Gill-Frerking \\ NTK Services, Concord, New Hampshire, USA
}

\begin{abstract}
Many museums and institutions have collections that include human mummies. Although some of the mummies may have been analyzed prior to or since acquisition, many have never been scientifically studied or have not been re-examined in decades. The rapid development of technology for the analysis of ancient human remains affords researchers the opportunity to gather new data about mummies that were discovered and examined decades, or even centuries, ago. The implementation of technology for the analysis of human mummies has become routine and provides substantial new information about the individuals being studied. During the re-analysis of a mummy, early post-excavation modifications, often previously unknown to current museum curators and staff, are identified and will, in some circumstances, affect the analysis and accurate interpretation of data. There are also ethical and professional guidelines that should be applied to the use of technology for the study of human remains, including mummies. Museums make the protection of all human remains a priority and any plans for research using human mummies must be carefully considered and planned. New data from any research based on mummies in museums can be, and should be, applied to both academic analysis and interpretation and public presentation. This paper reviews some of the effects of past post-excavation efforts on the re-analysis and interpretation of three Iron Age bog mummies from northern Germany and a child mummy from South America, and highlights issues for museums who are considering undertaking or permitting analysis of mummies in collections.
\end{abstract}

Keywords: mummies, museums, post-excavation, evidence-based methods, computed tomography, radiography 


\section{INTRODUCTION}

Radiology was used as part of a larger process of re-examination and re-analysis of several mummies. Radiological images revealed substantial post-excavation measures, in the form of wire and other materials to form, or maintain the condition of, some aspect of the mummies. This paper discusses the impact of historical conservation and display modifications on the re-analysis and reinterpretation of three Iron Age peat bog mummies from northern Germany, and a child mummy from South America.

\section{MATERIALS AND METHODS}

\section{Materials}

\section{Bog bodies}

A bog body is a human body that has been naturally preserved in acidic peat. The body may have soft tissue (i.e. skin, muscle, fat, connective tissue, internal organs) and/or keratinous structures (i.e. hair, fingernails and toenails), as well as hard tissue (i.e. bones and teeth), preserved to varying degrees. Acidic peat environments, such as those in which bog bodies were found, contribute to the preservation of soft and keratinous structures, but lead to substantial demineralization of hard tissues. Bog bodies have been found in northwest Europe, mainly Denmark, northern Germany, the Netherlands, Ireland and the United Kingdom. Most of the bog bodies on display, or otherwise held in the collections of museums, underwent limited examination at the time of excavation and analysis. A very few bodies, for example, Denmark's Grauballe Man and Tollund Man, were thoroughly analyzed shortly after discovery $(9,13,14,15$, 20). Recently, a few bog bodies have been re-examined and re-interpreted using new technology and fresh perspectives $(7,16)$.

As part of a larger project of re-analysis, several Iron Age bog bodies from the Stiftung Schleswig-Holsteinische Landesmuseen Schloss Gottorf in Schleswig, northern Germany, were re-examined using multi-slice computed tomography (MSCT) and medical imaging software (7). During medical imaging, evidence of museum conservation was discovered in all of the bodies examined; some of these adjustments were unknown to current museum personnel. Three of the bodies displayed substantial post-excavation conservation modifications that subsequently impacted the analysis and interpretation of the remains.

The body of an adult male was discovered during peat cutting in 1871 . The mummy, now known as "Rendswühren Man", was identified as ancient, and autopsied. Prior to being placed on display in a north German museum, the 
body was desiccated in an oven and photographed as part of the conservation process. Detailed records of the autopsy were placed in the museum archives, although specifics of the conservation process were very limited. There were no further bioarchaeological analyses of this body until recently. A piece of the textile accompanying the body was radiocarbon dated in 1995, with a resulting date of $1960 \pm 50 \mathrm{BP}(8)$. Skin samples from the body were recently radiocarbon dated to $1800 \pm 30 \mathrm{BP}$ to $1590 \pm 50 \mathrm{BP}$ (9). This mummy is usually on display as part of the Iron Age exhibition on the third floor of the Archäologisches Landesmuseum in Schleswig.

The headless corpse of an adult male, now known as the Dätgen Man, was recovered during peat cutting in 1959. Six months later, an isolated head was found in the same bog, about $3 \mathrm{~m}$ west of the legs of the headless corpse. Despite originally being assigned separate museum accession number, it has been assumed for decades that the head and the body are from the same individual, although this has not yet been conclusively determined. Museum conservation included treatment of the skin with pentachlorophenol, which drastically altered the original colour and texture of the skin and rendered the skin friable. Thin copper wire and steel wire were used to attach various parts of the skeleton that were at high risk for loss or damage, including the foot and hand bones and the rib cage. Although research was undertaken at the time of excavation, no further analyses had been conducted, until recently. Hair from the head excavated in 1960 was radiocarbon dated to $1760 \pm 80$ B.P. (9); no samples were taken from the headless body excavated in 1959. The body and the remains of the head are currently on display at the Archäologisches Landesmuseum in Schleswig in an exhibition featuring aspects of death in Iron Age northern Germany.

A third body, the so called "Windeby Child" was so extensively reconstructed that complete digital radiography and CT scanning could not be undertaken. Although it was possible to analyse the outer surface of the soft tissue part of the mummy and undertake separate osteological analysis of most of the skeleton, it was not possible to examine the body in detail using radiology. The mummified soft tissue part of the body is usually a focal point of the Iron Age bog body exhibition at the Archäeologisches Landesmuseum Schloss Gottorf; the skeletal elements not included in the reconstructed mummified body are usually kept in an environmentally-secure organic storage unit.

\section{Child mummy from South America}

The collection of the Buffalo Museum of Science, in Buffalo, New York, includes the mummy of a young child from Peru (catalogue number C2818). 
The mummy was given to the museum in 1905, along with a collection of textiles, and is believed to be pre-Columbian (17). At some point in the past, the mummy was permanently mounted to a backing board (pers. comm. - K. Leacock). The mummy is currently being studied, and little is known about the child at this point.

\section{Methods}

\section{Bog bodies}

Archive documents related to all three bodies were examined for data related to excavation, analysis and conservation. In the case of the Rendswühren Man, most of the documents were written in an old style of script that was very difficult to read. A senior member of the local community was contacted to arrange transcription of the original documents to modern written German. Since the style of script has not been used in some time, transcription provided a muchneeded process of documentation to ensure that the information will also be available for future research.

During the archive research, it immediately became apparent that many conservation processes and results of previous analyses were not documented. The extent of these processes and analyses became more obvious during the physical and radiological examinations of the bodies.

The bodies were transported to the Institute for Diagnostic Radiology in Kiel, Germany, and scanned using a Siemens Somatom Sensation 16 MSCT unit. Each body was also imaged using a Kodak Directview Digital Radiography unit.

\section{Child mummy from South America}

In April 2014, the mummy was taken to the Roswell Park Cancer Institute in Buffalo, New York, and scanned using a GE Light Speed VCT and pediatric scan protocols (Fig. 1). Data from the CT scan is currently being analyzed using two different medical imaging software packages. The aims of the medical imaging were to attempt to determine the sex and age of the child, identify any evidence of trauma or pathology, and note any post-excavation modifications to the body. 


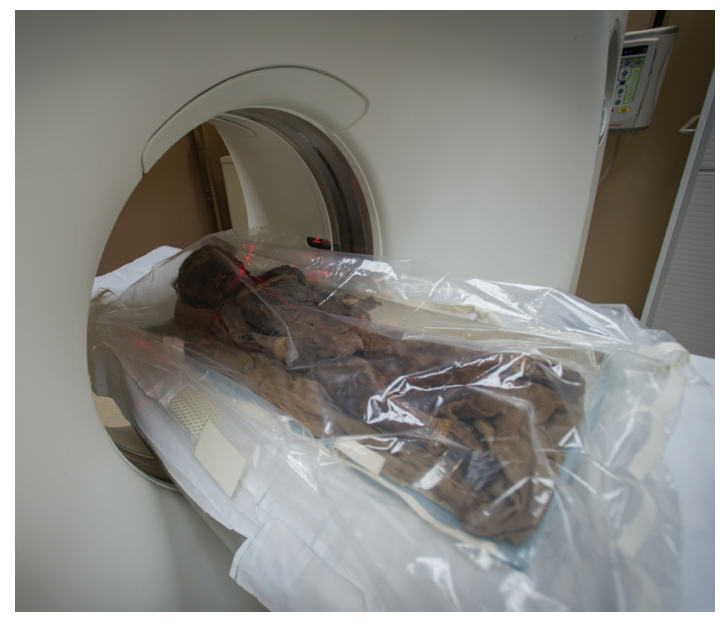

Figure 1. Child mummy from Peru in CT scanner. Mummy from the Collection of the Buffalo Museum of Science (C2818), photo courtesy Buffalo Museum of Science (Onion Studio).

\section{RESULTS}

\section{Rendswühren Man}

During standard assessment of the body to determine age-at-death, sex, health status and possible cause of death, problems arose during the review of the twodimensional images and three-dimensional virtual models constructed from the CT scans. Digital radiographs of the head of the Rendswühren Man provided the first indication of museum conservation. The head had been completely reconstructed using wire and several unknown materials (Fig. 2). Two thin metal rods were placed inside the skull, extending several centimetres, from near the top of the cranium into the neck, causing an unnatural lengthening of the neck. Several more metal rods provided a framework for the reconstructed skull while an unknown material, perhaps a type of modeling clay, was used for facial structure. Another, currently unidentified, material was used, very successfully, to replicate teeth in both appearance and texture. The head was filled with yet another unknown substance that resembled cotton wool on the images. Although there is information in the archives stating that the head had been reconstructed following a thorough autopsy, the extent of reconstruction and the materials used during the conservation process were not specified.

The wire in the head and neck caused substantial artefacts ("metal spray") that made it impossible to view aspects of the cervical vertebrae. Using medical imaging software, each individual vertebra, from the sacrum through to C5, was defined and viewed as a separate three-dimensional model; vertebrae $\mathrm{C} 1$ through C4 appear to be missing. Following a full autopsy of the mummy in 
1871, it was noted that the mummy had several fractures to the face and skull. Specifically, a "triangle-shaped injury" over the nasal bone; loose pieces of the frontal bone; a "star-shaped" fracture radiated from the underside of the right orbit through to the temporal bone and a shattered right parietal bone $(12,18)$ were identified. The interpretation at the time was that the temporal and parietal bones were damaged by a blow to the head, which seemed to have come from the right side of the head towards the left side and would have caused the injuries to the skull (12). Since there was little other evidence for trauma or pathology on the body, it is possible that these reported injuries may have been the cause of death for this man. Since there are no pieces of the skull remaining, despite an impressively reconstructed head, it is impossible to reassess the injuries described in the autopsy report. In bog bodies, postmortem fractures often misinterpreted as perimortem. Owing to the conservation, and the unfortunate loss of the skull bones, the cause of death for the Rendswühren Man must remain purely speculative and can only be based on the autopsy report.

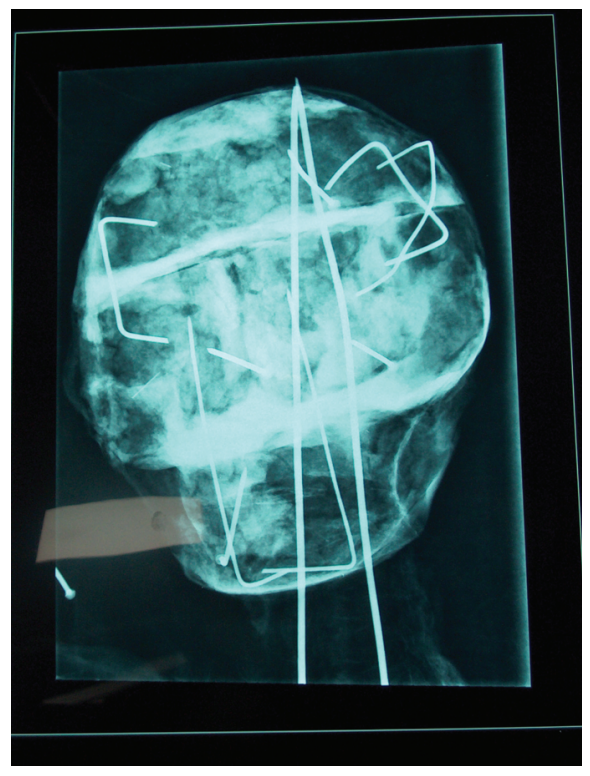

Figure 2. Rendswühren Man: reconstruction of the skull using wire and unknown materials. Image by Heather Gill-Frerking.

\section{Dätgen Man}

The pentachlorophenol used during the conservation caused the skin to become very delicate. Physical examinations were limited, to some extent, because of the fragile nature of the skin and movement of the mummy was kept to an absolute minimum. Since pentachlorophenol is toxic, a respirator mask, nitrile gloves 
and a separate full-length lab coat were used any time the researcher worked with the body. Several ribs had been removed at some point during the preparation of the body. The current location of these ribs is unknown.

There were several fractures on the body. Most of these fractures were originally interpreted as perimortem, but the re-analysis indicated that most of the fractures were, in fact, postmortem. Most of the postmortem fractures occurred during the movement of the body in the peat over two millennia; some fractures may also have occurred during excavation, transportation and conservation. The right radius and ulna, devoid of soft tissue, were bound together with thin copper wire at the distal end. The distal end of the left of humerus was also wrapped in copper wire. The right ulna was linked to the humerus by steel wire and the entire left hand was also re-articulated using steel wire. The entire rib cage is held together by a fine steel wire and wire is protruding from several of the sternal rib ends (Fig. 3). A large, plastic-coated wire protruded from the sacrum and appeared to have connected the lumbar vertebrae. The pelvis was wired together at the pubic symphysis. A wooden rod protruded from right femur. It had been inserted at some point to keep the distal end of the femur in place. The right tibia and fibula were attached with copper wire. All of the bones of both feet, except the left calcaneus, were fully articulated using steel wire, copper wire and small nails.

The wire, once again, caused metal artefacts that impacted the analysis of the skeletal material from the medical images. Examination and interpretation of fractures and other potential trauma as perimortem or postmortem is critical for bog bodies, since there is a common perception that bog bodies were often subjected to exceptional physical mutilation at the time of their death (1). Re-analysis of the bones of Danish bog bodies has demonstrated that many fractures were postmortem, not perimortem (10). The presence of the wire at the point of fracture on so many bones, and resulting imaging artefacts, prevented the bones from being accurately visualized at some points, requiring exceptional care in order to ensure that interpretation was correct. Finally, the wire that was placed at the pubic symphysis, to connect both halves of the pelvis, was exceptionally problematic. The pubic symphysis is an important area for the estimation of age-at-death in skeletal remains. The imaging artefacts caused by the wire prevented a clear image of this section of the pelvis, unfortunately rendering it useless as an age estimation indicator in this body. 


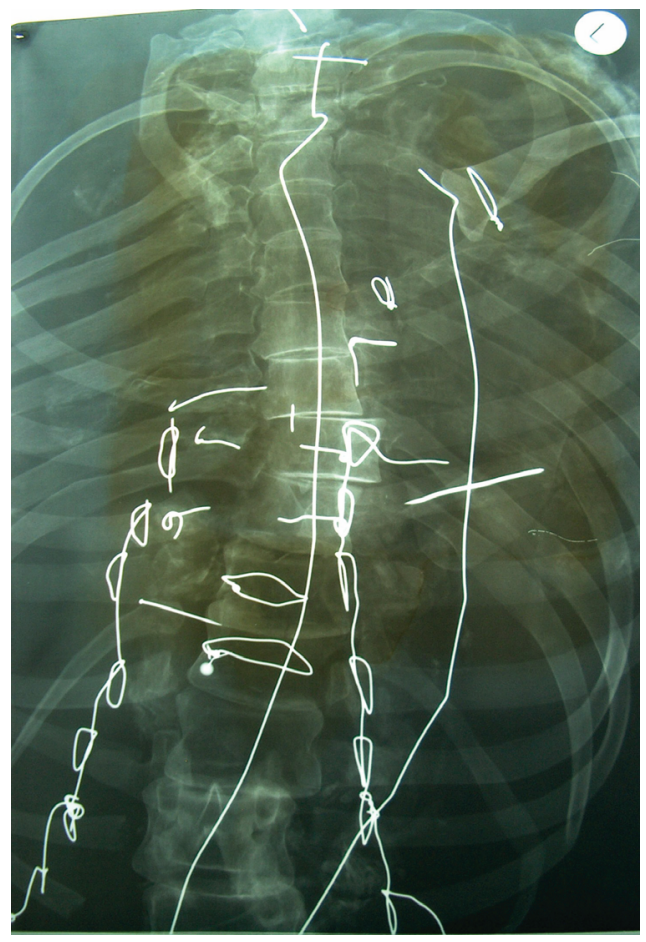

Figure 3. Dätgen Man: Reconstructive and support wire in the thorax.

Image by Heather Gill-Frerking.

\section{Windeby Child}

During the preparation of the body for display in the early 1950s, most of the skeletal material was removed from the adolescent and placed in a separate storage area. Only the original left scapula, both left and right clavicles and several ribs were included as part of the reconstructed body on display. The skin and soft tissue had been preserved using an unknown chemical treatment; this tissue is firm to the touch and quite hard in places. The original skull is in storage, but the head was reconstructed using plaster, with what appears to be the original skin and hair over the surface of the plaster. A replica band cover the area of the eyes; when the body was found, there was a woven band across the eyes, which is suggested by some to be a blindfold (e.g. 9). The nose is distorted and the face that exists on the body today does not closely resemble the original structure of the face. The head is loosely attached the body via a wooden pole, which extends into the neck area. This area is covered by the original ox-hair cape.

In terms of the post-cranial body, the body position was substantially altered from the time of discovery. The body is posed in a more "alluring", open body posture, which may be a reflection of the original interpretation of the individual as an "adulteress". The re-analysis of the skeletal remains of the body 
indicates that the body is not, as originally believed, a 12-14 year old female, but an adolescent male (6). There is no soft tissue remaining in the abdominal area or genital area and the determination of sex via the presence of soft tissue was not possible. This body is placed on a mock peat mound, with more mock peat overlying the majority of the chest, abdomen and pelvis. The feet are at an unnatural angle, appear darker than other parts of the body and the texture of the skin surface is different. There are other aspects of the reconstruction that affected the interpretation (see 2, 4 for discussion), but did not impact the recent re-analyses.

In order to support the mock peat mound and the reconstructed body, a wood frame, tented in the middle, was assembled. The sheer size, weight and awkwardness prevented the body from being transported for medical imaging, which restricted the analysis of the soft tissue remains. In this case, the conservation efforts hindered the re-analysis, and potential improved interpretation, of the body. The majority of the recent re-analysis and re-interpretation is based mainly on the skeletal material that had been removed from the body during conservation.

Conservation efforts affecting analysis and interpretation of the Windeby Child were not limited to the preparation of the body for display. The body had, for example, been found with the brain intact in the skull. During original analyses, the brain was removed; its current location is unknown (7). The skeletal material was also subject to conservation. Putty was used to fill two small, shallow, concave pits on the cranium. The putty was then covered with a dark brown paint, to match the colour of the bone. Full assessment of the pits as either potentially pathological or potentially taphonomic could not be undertaken because of the putty. There is evidence of a white substance in some of the cranial sutures, as well as traces of a blue plasticine-like material on the right coronal and lambdoid sutures. It is possible that this material stems from earlier analyses of the skeleton. Other features of the skull, including point bregma and both coronal sutures were filled with putty or thick, transparent glue. This made it difficult to see the necessary features for assessing age-atdeath from the skull. Although teeth were present at the time of excavation (11), these location of these teeth are currently unknown. Several parts of the post cranial skeleton were patched with putty or covered with a paint-like substance, possibly a preservative. Bones affected include the right scapula, all of the right upper limb bones, the left femur. The preservative materials did not affect the image analysis of the bone. Direct physical analysis of some bones, including some areas necessary for the estimation of age, was, however, restricted. 


\section{South American child mummy}

Conservation work undertaken on the mummy in 2005 was well documented (17) and did not affect the quality of the scan data, or the interpretation of the scan data. Prior to the scan, an examination of the mummy backing board revealed the presence of several small tacks on the side of the backing board and another tack near the neck region of the mummy. Fortunately, the presence of the tacks did not seriously affect the quality of the scan data. Although there are some imaging artefacts from the presence of the metal, these were very limited. An object resting near the right shoulder area of the back was clearly not organic: it had sharp, straight edges and a sharply different density to the surrounding bone and soft tissue. The nature of this object has yet to be determined.

\section{DISCUSSION}

Limitations to the re-analysis of all three bog bodies resulted from historical museum conservation efforts. The application of known and unknown chemical substances to preserve skin and other soft tissues affected the physical reexamination of both the Windeby Child and the Dätgen Man. In the case of the Windeby Child, application of preservatives and putty reduced the number of areas available for osteological estimation of age-at-death. Use of reconstructive materials had substantial negative impact on the re-analysis of all three mummies. The presence of wire, for example, caused imaging artefacts that obscured osteological landmarks and features necessary for accurate analysis. The complete reconstruction of the Rendswühren skull prevented a re-assessment of the cause of death suggested by an 1871 autopsy.

While some aspects of the restoration were known prior to the recent reanalyses, the extent of the reconstruction was not. Many of the aspects of conservation were not recorded and there were seldom any details in archive files to document conservation materials and techniques. The physical re-analysis, digital radiology and computed tomography did provide substantial new data for the re-interpretation of all three bodies (7), despite the limitations caused by the historical methods of conservation.

In the case of the child mummy from South America, the imaging artefacts caused by the presence of metal tacks on the backing board, were minimal and should not affect the interpretation of the CT scan data.

The mummies included in this study are far from the only mummies with post-excavation conservation and modification, most of the effects of which were detected through radiography. Other examples include the Grauballe Man, a Danish bog body in which four vertebrae had been replaced with synthetic 
sponges (3) and a mummy from Ptolemaic Egypt with a metal rod running from the skull into the thorax as a form of stabilization (19). It is likely, however, that there are still many other mummies that were modified during conservation.

\section{CONCLUSIONS}

It is acknowledged that modern museum conservation methods are considerably different from those used with the mummies excavated decades or centuries ago. The techniques and materials used were often appropriate for the time. No doubt museum curators considered new approaches for the long-term preservation and protection of the mummies and the selected techniques were utilised for specific reasons.

The purpose of the re-examination of mummies in museum collections is to ensure that valuable data about the individuals and how they lived in the past is made available to both academic researchers and the general public. New technology is enabling extensive re-assessment and re-interpretation of mummies from many museum collections. It is strongly recommended, however, that a multidisciplinary evidence-based approach (5) to the research of either single or multiple mummies in museums, schools and other institutions is applied. As part of the evidence-based approach, it is recommended that those who undertake analysis of mummies are experienced in the analysis of ancient human remains with soft tissue, or that mummy specialists are included as part of multidisciplinary research teams.

Museums with mummies in their collections should be aware of the importance of the re-analysis of mummies and the impact of current methods of conservation on potential future analyses. Detailed documentation of all changes made to the mummy during conservation is essential and, if possible, documentation should include photographic and radiographic images of the body before and after conservation. If materials alternative to metals are available and feasible for reconstruction and stabilization, the quality of analysis possible through medical imaging will be enhanced.

The re-analysis of mummies in museum collections provides an opportunity to gather data about, and possibly re-interpret, the life and death of the individual. This, in turn, provides additional information for museum displays, as well as contributing data to the understanding of the population from which the mummy originates. The collaboration between museums and mummy researchers is an important partnership; both museums and mummy researchers also need to be aware of the impact of historical and modern conservation techniques on the potential re-analysis of the mummies. 


\section{ACKNOWLEDGEMENTS}

The author wishes to thank the Stiftung Schleswig-Holsteinische Landesmuseen Schloss Gottorf (Schleswig, Germany) for unrestricted access to all of the bog bodies at the museum. CT scanning was undertaken with the kind assistance of the Institute for Diagnostic Radiology of Christian Albrechts University (Kiel, Germany). Some of the image editing was done by Damien Reinhart and James Schanandore from North Dakota State University (Fargo, USA). The bog body research was funded in part by the Deutscher Akademischer Austausch Dienst (DAAD); a Duff Roblin Fellowship from the University of Manitoba (Winnipeg, Canada) and Dr Robert Hoppa, Canada Research Chair in Skeletal Biology, University of Manitoba (Winnipeg, Canada). The author would also like to thank the Buffalo Museum of Science, especially curator Kathy Leacock, and the Department of Diagnostic Imaging at the Roswell Park Cancer Center in Buffalo, New York for access to, and medical imaging of, the child mummy from Peru.

\section{REFERENCES}

1. Asingh P. (2007). The magical bog. In: Asingh P., Lynnerup N. (eds), Grauballe Man: An Iron Age Bog Body Revisited. Moesgaard Museum and Jutland Archaeological Society. Aarhus, 275-289.

2. Burmeister S. (2007). Moorleichen als Opfer: Deutungsmuster einer problematischen Fundgruppe. In: Burmeister S., Derks H., von Richtofen J. (eds), ZWEIUNDVIERZIG: Festschrift für Michael Gebühr zum 65. Geburtstag. Verlag Marie Leidorf. Rahden (Westf.), 91-106.

3. Frohlich B. (2007). The search for Grauballe Man's missing vertebrae. In: Asingh P., Lynnerup N. (eds), Grauballe Man: An Iron Age Bog Body Revisited. Moesgaard Museum and Jutland Archaeological Society. Aarhus, 218-225.

4. Gebühr M. (2002). Moorleichen in Schleswig-Holstein. Wacholtz Verlag. Neumünster.

5. Gill-Frerking H.C. (ed.)(Forthcoming). Mummy Studies: An Evidence-Based Approach. Cambridge University Press. Cambridge.

6. Gill-Robinson H.C. (2007). Hidden in Plain Sight: The Story of the Windeby Child. In: Burmeister S., Derks H., von Richtofen J. (eds), ZWEIUNDVIERZIG: Festschrift für Michael Gebühr zum 65. Geburtstag. Verlag Marie Leidorf. Rahden (Westf.), 107-112

7. Gill-Robinson H.C. (2005). The Iron Age Bog Bodies of the Archaeologisches Landesmuseum, Schloss Gottorf, Schleswig, Germany. Unpublished PhD Thesis, Department of Anthropology, University of Manitoba, Winnipeg, Canada.

8. Glob P.V. (1956). Jernaldermanden fra Grauballe. KUML: Årbog for Jysk Arkæologisk Selskab, 1956, 99-113. 
9. Glob P.V. (1988). The Bog People. Faber. London.

10. Gregersen M., Jurik A.G., Lynnerup N. ( 2007). Forensic evidence, injuries and cause of death. In: Asingh P., Lynnerup N. (eds), Grauballe Man: An Iron Age Bog Body Revisited. Moesgaard Museum and Jutland Archaeological Society Aarhus, 234-259.

11. Hage W. (1958). Röntgenuntersuchungen an der Moorleichen I und II von Windeby. Praehistorische Zeitschrift, 36, 166-171.

12. Handelmann H. (1871). 181/1871 L: Randnotiz. Unpublished document in the archives of the Archaeologisches Landesmuseum, Schloss Gottorf, Schleswig, dated 30 June 1871.

13. Helbæk H. (1951). Tollund Mandens sidste maaltid. Aarbøger for Nordisk Oldkyndighed og Historie, 1950, 311-341.

14. Helbæk H. (1959a). Grauballemandens sidste måltid. KUML: Årbog for Jysk Arkæologisk Selskab, 1958, 83-116.

15. Helbæk H. (1959b). Botanical study of the stomach contents of Tollund Man. Aarbøger for Nordisk Oldkyndighed og Historie, 1958, 329-341.

16. Lynnerup N. (2007). Mummies. Yrbk Phys Anthropol, 50, 162-190.

17. Page K.M. ( 2012). Human remains in a museum's collection: Implications for collections management. Bulletin of the Buffalo Society of Natural Sciences, 41: 11-28.

18. Plessen S. (1871) Aus dem amtlichen Obductions-Protokoll. Unpublished document in the archives of the Archaeologisches Landesmuseum, Schloss Gottorf, Schleswig, dated 6 June 1871.

19. Rühli F.J., Psota T. Böni T. (2007). Die Mumie eines unbekannten Individuums, Ptolemäerzeit. In: Wieczorek A., Tellenbach M., Rosendahl W. (eds), Mumien: Der Traum vom ewigen Leben. Philipp von Zabern and Reiss-Engelhorn Museen. Mainz am Rhein, 337-339.

20. Thorvildsen K. (1951). Moseliget fra Tollund. Aarboger for Nordisk Oldkyndighed og Historie, 1951, 303-310.

21. van der Plicht J., van der Sanden W.A.B., Aerts A.T., Streurman H.J. (2004). Dating bog bodies by means of ${ }^{14}$ C-AMS. J Archaeol Sci, 31,471-491.

22. van der Sanden W. (1995). C14-Datierungen von Moorleichen aus Niedersachsen und Schleswig-Holstein. Die Kunde N.F., 46, 137-155

\section{Address for correspondence:}

Dr Heather Gill-Frerking

NTK Services

P.O. Box 4197

Concord, New Hampshire, 03301, USA

E-mail: heather@ntknet.com 